\title{
Multiple Shoots Induction and Rapid Propagation of Lonicera Edulis
}

\author{
Qige Qi, Chunyan Guo, Qichang Zhang* \\ College of Forestry, \\ Beihua University, \\ Jilin, 132013, China
}

\begin{abstract}
Sprouts being explants, the factors affecting in vitro culture and plant regeneration of $L$. edulis were optimized by orthogonal design and tissue cultured seedlings were obtained on culture media with different concentrations of hormones. The results showed that the optimum compositions for primary culture, subculture and rooting culture were MS+6-BA $1.0 \mathrm{mg} / \mathrm{L}+$ IBA $0.2 \mathrm{mg} / \mathrm{L}$, MS+6-BA $0.5 \mathrm{mg} / \mathrm{L}+\mathrm{IBA} \quad 0.3 \mathrm{mg} / \mathrm{L}+\mathrm{KT} 1.5 \mathrm{mg} / \mathrm{L}$ and 1/4MS+IBA $1.5 \mathrm{mg} / \mathrm{L}$. The differentiation rate, proliferation coefficient and rooting rate on these media were up to $100 \%$, 8.7 , and $96.7 \%$ respectively. The combination of $6-\mathrm{BA}$, IBA and KT was effective in the number of multiple shoots of $L$. edulis in subculture. The micro-propagation technology introduced to cultivate the tissue cultured seedlings proved to meet the need of rapid propagation of plantlets and could be applied in mass propagation.
\end{abstract}

Keywords-lonicera edulis; multiple shoots; tissue culture; rapid propagation

\section{INTRODUCTION}

L. edulis Turcz., the deciduous shrub of Caprifoliaceae L. edulis subgroup, succeeds Vaccinium uliginosum L., Ribes nigrum L., and Rubus spp. to become another emerging small berry species ${ }^{[1]}$. L. edulis Turcz., known for its functions such as detoxification, stabilizing blood pressure, improving the detoxification function of liver, anti-tumor, anti-fatigue and promoting physical development, produces edible fresh fruits and is suited for making drinks, jam, fruit cake and wine. It is also suitable for the extraction of natural mauve pigment ${ }^{[2]}$. Studies on L. edulis Turcz. have been paid special attention to in Russia, where breeding began in 1950s, and 60 varieties were applied to farming and cultivation for commercial production in $1990 \mathrm{~s}^{[3]}$. Breeding of new L. edulis varieties started in Japan in 1980s, and there has been promotion and application of 'Yufutsu' and other varieties ${ }^{[4]}$. Domestication, cultivation trials, and the development of wild $L$. edulis fruits in China started in $1980 \mathrm{~s}^{[5]}$, but breeding of new varieties and cultivation of quantitative experimental cultivation have just begun. Tissue culture studies of $L$. edulis subgroup have been slightly reported ${ }^{[6-}$ ${ }^{7]}$, and there has been no experimental system of tissue culture or in vitro rapid propagation that is particularly suitable for production and application. This study on inducing adventitious shoots and screening seedling and rooting media resulted in appropriate compositions for the primary culture, subculture, seedling, and rooting of $L$. edulis. It also resulted in rapid propagation techniques that suit $L$. edulis production, and laid the foundation for future researches.

\section{MATERIAL AND METHOD}

\section{A. Selecting and sterilizing explants}

Hibernating $L$. edulis branches from Changbai Mountain area were taken to lab hydroponics in March 2005, and the germinated sprouts served as experimental material. First, soak hydroponic buds in water with a small amount of detergent (1 to 2 horn scoops of detergent into $100 \mathrm{ml}$ water), soak and stir for $2 \sim 3 \mathrm{~min}$, then rinse with running water for $1 \sim 2 \mathrm{~h}$. Finally, sterilize with $0.1 \%$ of $\mathrm{HgCl}_{2}$ solution for 6 min on the super clean bench, and then rinse with sterile water eight times.

\section{B. Screening basal medium}

Graft the sterilized explants onto MS, $\mathrm{N}_{6}, \mathrm{~B}_{5}, \mathrm{H}$ and White media supplemented with 6-BA $1.0 \mathrm{mg} / \mathrm{L}$, IBA $0.2 \mathrm{mg} / \mathrm{L}$. Observe the growth to screen the basal media suitable for $L$. edulis.

\section{Primary culture}

Add 6-BA (1.0, 2.0, $3.0 \mathrm{mg} / \mathrm{L})$ and IBA (0.1, 0.2, 0.3 $\mathrm{mg} / \mathrm{L}$ ) with different concentrations to the selected basal media. Use two-factor and three-level orthogonal design. Repeat each treatment three times. Graft 30 bottles with each repeat. Compute differentiation rate of each treated shoot (shoot differentiation rate $=$ number of differentiated bottles / (number of graft bottles - number of contaminated bottles)) after 30 days. Observe the growth after 40 days.

\section{Propagation in subculture}

Regulate the concentrations of 6-BA and IBA, plus $\mathrm{KT}$, on the basis of primary culture. Experiment the first 3 lines according to $\mathrm{L}_{9}\left(3^{4}\right)$. Set three repeats for each treatment. Graft 30 bottles with each repeat. Observe shoot elongation and the number of multiple shoots. Screen the optimum combination of hormones. Calculate proliferation coefficient (proliferation coefficient $=$ total of germinated sprouts / number of explants that germinate sprouts).

\section{E. Rooting culture}

Use micro-cuttings from seedling for rooting, and MS, 1/2MS, 1/4MS supplemented with NAA or IBA of different concentrations as rooting media. Compute each treated rooting rate (rooting rate $=$ number of rooted 
micro-cuttings / number of micro-cuttings for rooting culture) after 40 days when the number of rooted seedlings stabilized.

\section{F. Tissue culture conditions}

Add to all media agar $10 \mathrm{~g} / \mathrm{L}$ and sucrose $30 \mathrm{~g} / \mathrm{L}$. Adjust the $\mathrm{pH}$ to 5.8 before autoclaving. Maintain the culture room temperature at $(25 \pm 1){ }^{\circ} \mathrm{C}$, light $13 \mathrm{~h} / \mathrm{d}$, light intensity $2000 \mathrm{~lx}$.

\section{G. Statistical analysis}

Percentage data from observations require arcsine transformation. Use SAS8.2 software for analyzing and processing data, and Duncan method for testing the significance of differences. Results are expressed as mean \pm standard error ${ }^{[8]}$.

\section{RESULTS AND ANALYSES}

\section{A. Effects of the basal media on explants induction and differentiation}

As can be seen in Table I, MS medium had the best effect on $L$. edulis induction and differentiation, $\mathrm{N}_{6}$ and $\mathrm{B}_{5}$ media had the second best effect, and $\mathrm{H}$ and White media the worst. Observation suggests that MS medium had an evident effect on $L$. edulis shoots differentiation, the differentiation rate being 98.5 percent. Explants grew well on the medium, and multiple shoots appeared. The differentiation rates of $\mathrm{N}_{6}$ and $\mathrm{B}_{5}$ media being $71.6 \%$ and $68.5 \%$, explants grew alright and had a few multiple shoots. The differentiation rates of $\mathrm{H}$ and White media being $63.6 \%$ and $62.3 \%$, explants turned white as a whole, with vulnerable leaves and moribund, and only a few explants had multiple shoots.

TABLE I. EFFECT OF BASAL MEDIA ON INDUCTION AND DIFFERENTIATION OF L. EDULIS

\begin{tabular}{lllll}
\hline $\begin{array}{l}\text { Culture } \\
\text { medium }\end{array}$ & $\begin{array}{l}\text { Number } \\
\text { of } \\
\text { grafted } \\
\text { shoots }\end{array}$ & $\begin{array}{l}\text { Number of } \\
\text { contaminated } \\
\text { shoots }\end{array}$ & $\begin{array}{l}\text { Number of } \\
\text { differentiated } \\
\text { shoots }\end{array}$ & $\begin{array}{l}\text { Differentiation } \\
\text { rate }\end{array}$ \\
\hline MS & 80 & 12 & 67 & 98.5 \\
$\mathrm{~N}_{6}$ & 80 & 13 & 48 & 71.6 \\
$\mathrm{~B}_{5}$ & 80 & 7 & 50 & 68.5 \\
$\mathrm{H}$ & 80 & 14 & 42 & 63.6 \\
White & 80 & 11 & 43 & 62.3 \\
\hline
\end{tabular}

B. Effects of hormone combinations on explants induction and differentiation in primary culture

$5 \sim 7 \mathrm{~d}$ after $L$. edulis explants were grafted on axillary sprout induction media, they began to sprout with small green protrusions appearing and gradually elongating. After $10 \mathrm{~d}$ the sprouts grew to $1.4 \sim 1.6 \mathrm{~cm}$, and after $30 \mathrm{~d}$ the sprouts turned light green, the average height $3.9 \mathrm{~cm}$ (Figure 1A). The treated explants were significantly different in differentiation rate (Table II). As can be seen in Table II, L. edulis explants had the highest differentiation rate of $100 \%$ in 6-BA $1.0 \mathrm{mg} / \mathrm{L}+$ IBA 0.2 $\mathrm{mg} / \mathrm{L}$ composition, significantly different $(\mathrm{P}<0.01)$ from other treated explants.
ANOVA results showed that hormones 6-BA and IBA and their interaction had a very significant effect $(\mathrm{P}<0.01)$ on $L$. edulis shoot differentiation rate. $F$ values in descending order were 6-BA (45.72), IBA (37.12), their interaction (22.49), indicating that 6-BA had the biggest effect on shoot differentiation, followed by IBA, and their interaction. The new Duncan method was used for multiple comparisons to find the optimum culture composition. The results showed that among the three levels of 6-BA, the difference was significant between 1.0, 2.0 and $3.0 \mathrm{mg} / \mathrm{L}(\mathrm{P}<0.01)$, the average differentiation rate being $69.7 \%, 60.7 \%$ and $39.3 \%$. The $1.0 \mathrm{mg} / \mathrm{L}$ level was selected according to the average percentage. Among the three levels of IBA, the difference was significant between $0.1,0.2$, and $0.3 \mathrm{mg} / \mathrm{L}$, the average differentiation rate being $61.6 \%, 67.2 \%$ and $40.9 \%$. The $0.2 \mathrm{mg} / \mathrm{L}$ level was selected according to the average percentage. MS +6- BA $1.0 \mathrm{mg} / \mathrm{L}+$ IBA $0.2 \mathrm{mg} / \mathrm{L}$ turned out to be the optimal hormone combination for multiple shoots induction and L2 composition of the orthogonal experiment. The treated shoots had the average differentiation rate of $100 \%$ and robust axillary sprouts, being the optimum multiple shoot induction composition.

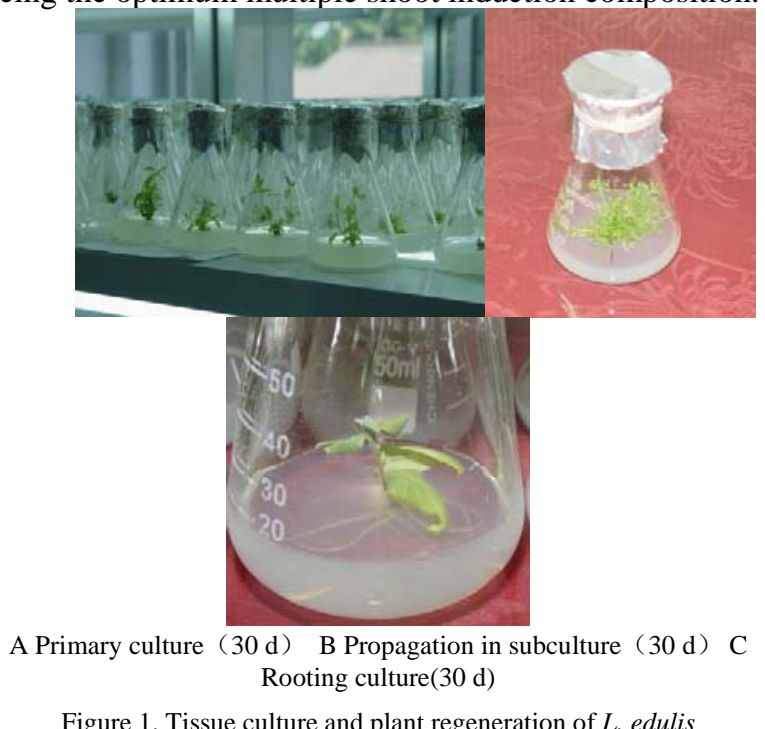

Figure 1. Tissue culture and plant regeneration of $L$. edulis 
TABLE II. EFFECT OF HORMONE COMBINATIONS ON EXPLANT INDUCTION AND DIFFERENTIATION OF L. EDULIS IN PRIMARY CULTURE

\begin{tabular}{|c|c|c|c|c|}
\hline \multirow[t]{2}{*}{ Treatment } & \multicolumn{2}{|c|}{$\begin{array}{l}\text { Hormone combination / } \\
\text { (mg.L-1) }\end{array}$} & \multicolumn{2}{|c|}{ Differentiation rate } \\
\hline & 6-BA & IBA & & \\
\hline L1 & $1(1.0)$ & $1(0.1)$ & $\mathrm{bBC}^{64.6}$ & \pm 3.46 \\
\hline L2 & $1(1.0)$ & $2(0.2)$ & 100.0 & $00 \mathrm{aA}$ \\
\hline L3 & $1(1.0)$ & $3(0.3)$ & $\begin{array}{l}44.4 \\
\text { cdCDE }\end{array}$ & \pm 5.56 \\
\hline L4 & $2(2.0)$ & $1(0.1)$ & $67.5=$ & $32 \mathrm{bB}$ \\
\hline L5 & $2(2.0)$ & $2(0.2)$ & bcBCD & \pm 3.50 \\
\hline L6 & $2(2.0)$ & $3(0.3)$ & $\begin{array}{l}54.2 \\
\text { bcdBCD }\end{array}$ & \pm 4.17 \\
\hline L7 & $3(3.0)$ & $1(0.1)$ & $\begin{aligned} 52.8 \\
\text { bcdBCD }\end{aligned}$ & \pm 2.78 \\
\hline L8 & $3(3.0)$ & $2(0.2)$ & $\mathrm{dDE}^{41.1}$ & \pm 4.84 \\
\hline L9 & $3(3.0)$ & $3(0.3)$ & $24.1=$ & $3 \mathrm{eE}$ \\
\hline
\end{tabular}

Note: Different letters following the numbers suggest significant differences, small letters indicating $\mathrm{P}<0.05$ and big letters $\mathrm{P}<0.01$. It is the same in Table III

\section{Effects of hormone combinations on sprouts proliferation in subculture}

Axillary sprouts induced on stems were cut off for subculture on media. New axillary sprouts came out after $10 \mathrm{~d}$, and after $30 \sim 40 \mathrm{~d}$ in subculture the proliferation coefficient was 1.3 to 8.7 (Figure 1B). As can be seen in Table 3, different hormone combinations resulted in significantly different sprout proliferation coefficients. 6BA $0.5 \mathrm{mg} / \mathrm{L}+$ IBA $0.3 \mathrm{mg} / \mathrm{L}+\mathrm{KT} 1.5 \mathrm{mg} / \mathrm{L}$ had the highest sprout proliferation coefficient, significantly different from other media $(\mathrm{P}<0.01)$.

ANOVA results showed 6-BA, $\mathrm{KT}$, and the interaction of 6-BA, IBA and KT had a highly significant effect on proliferation in subculture $(\mathrm{P}<0.01)$, the effect of IBA being significant $(\mathrm{P}=0.0365<0.05)$. F values of 6 - $\mathrm{BA}$, $\mathrm{KT}$, the interaction of $6-\mathrm{BA}$, IBA and $\mathrm{KT}$, and IBA were $89.15,28.00,9.77$ and 4.00 , indicating that 6-BA had the greatest impact on multiple shoots from proliferation in subculture, followed by KT, the above interaction, and IBA. Further new Duncan test showed that among the three levels of 6-BA, $0.5 \mathrm{mg} / \mathrm{L}$ had the maximum average proliferation coefficient (6.0), significantly different from the other two levels $(\mathrm{P}<0.01)$. Among the three levels of IBA, $0.3 \mathrm{mg} / \mathrm{L}$ had the maximum average multiplication factor (4.0), significantly different from the other two levels $(\mathrm{P}<0.05)$. Among the three levels of $\mathrm{KT}$, $1.5 \mathrm{mg} \mathrm{/} \mathrm{L} \mathrm{had} \mathrm{the} \mathrm{maximum} \mathrm{average} \mathrm{proliferation}$ coefficient (4.9), significantly different from the other two levels $(\mathrm{P}<0.01)$. MS +6- BA $0.5 \mathrm{mg} / \mathrm{L}+$ IBA $0.3 \mathrm{mg} / \mathrm{L}$ $+\mathrm{KT} 1.5 \mathrm{mg} / \mathrm{L}$ proved to be the optimal combination of the three hormones in subculture and M3 composition in orthogonal experiment, the proliferation coefficient being 8.7.
TABLE III. EFFECT OF HORMONE COMBINATIONS ON ADVENTITIOUS SHOOT PROLIFERATION OF L. EDULIS IN SUBCULTURES

\begin{tabular}{|c|c|c|c|c|}
\hline \multirow[t]{2}{*}{ Treatment } & \multicolumn{3}{|c|}{ Hormone / (mg.L-1) } & \multirow{2}{*}{$\begin{array}{l}\text { shoot proliferation } \\
\text { coefficient }\end{array}$} \\
\hline & 6-BA & IBA & $\overline{\mathrm{KT}}$ & \\
\hline M1 & $1(0.5)$ & $1(0.1)$ & $1(0.5)$ & $5.0 \pm 0.58 \mathrm{bB}$ \\
\hline M2 & $1(0.5)$ & $2(0.2)$ & $2(1.0)$ & $4.3 \pm 0.33 \mathrm{bcBC}$ \\
\hline M3 & $1(0.5)$ & $3(0.3)$ & $3(1.5)$ & $8.7 \pm 0.67 \mathrm{aA}$ \\
\hline M4 & $2(1.0)$ & $1(0.1)$ & $2(1.0)$ & 2.3 $\pm 0.33 d e f$ ED \\
\hline M5 & $2(1.0)$ & $2(0.2)$ & $3(1.5)$ & $3.3 \pm 0.33 \mathrm{cdBCD}$ \\
\hline M6 & $2(1.0)$ & $3(0.3)$ & $1(0.5)$ & $1.3 \pm 0.00 \mathrm{fE}$ \\
\hline M7 & $3(1.5)$ & $1(0.1)$ & $3(1.5)$ & $2.7 \pm 0.33 \mathrm{deCDE}$ \\
\hline M8 & $3(1.5)$ & $2(0.2)$ & $1(0.5)$ & $1.7 \pm 0.33$ ef $E D$ \\
\hline M9 & $3(1.5)$ & $3(0.3)$ & $2(1.0)$ & $2.0 \pm 0.00$ ef ED \\
\hline
\end{tabular}

\section{Screening rooting compositions}

The seedlings obtained from propagation in subculture grew slow and stayed weak, unfit for rooting induction. When they grew to $1.5 \mathrm{~cm}$ or more after being cultivated on hormone-free MS medium of for a period of time, the seedlings were transplanted onto the rooting medium for rooting induction. The seedlings began to root after $20 \mathrm{~d}$ and the number of rooted shoots stabilized after $30 \sim 40 \mathrm{~d}$ (Fig. 1C). The rooting rate of each treatment, average root length, average number of rooted shoots are shown in Table 4.

As can be seen in Table IV, the rooting rate of different treatments after $40 \mathrm{~d}$ were $11.7 \% \sim 96.7 \%$, the average root length being $0.6 \sim 1.5 \mathrm{~cm}$, the average root number ranging from 1.3 to 5.0. ANOVA results showed that $F$ values of rooting rate, root number and root length for each treatment were $24.37,17.71$, and 78.03 . P values were less than 0.0001 , indicating that the effects of each treatment on rooting rate, root number and root length reached highly significant level. Among different treatments, $1 / 4 \mathrm{MS}+$ IBA $1.5 \mathrm{mg} / \mathrm{L}$ proved to be the optimum rooting composition, with the rooting rate of $96.7 \%$, the average root number being 5 and the root length $1.5 \mathrm{~cm}$ for each sterile seedling. 
TABLE IV. EFFECT OF HORMONE COMBINATIONS ON ROOTING OF $L$. EDULIS MICRO-CUTTINGS

\begin{tabular}{|c|c|c|c|c|}
\hline $\begin{array}{l}\text { Treatme } \\
\text { nt }\end{array}$ & $\begin{array}{l}\text { Experimental } \\
\text { composition }\end{array}$ & $\begin{array}{l}\text { Rooting } \\
\text { rate } / \%\end{array}$ & $\begin{array}{l}\text { Number of } \\
\text { roots } \\
\text { microcuttin } \\
\mathrm{g}\end{array}$ & $\begin{array}{l}\text { Root } \\
\text { length } \\
/ \mathrm{cm}\end{array}$ \\
\hline N1 & $\begin{array}{l}\text { 1/4MS+IBA1.5 } \\
\text { mg/L+NAA0.0mg/ } \\
\text { L }\end{array}$ & $\begin{array}{l}96.7 \pm 1.67 \\
\mathrm{a}\end{array}$ & $5.0 \pm 0.00 \mathrm{a}$ & $\begin{array}{l}1.5 \pm 0.0 \\
0 \mathrm{a}\end{array}$ \\
\hline N2 & $\begin{array}{l}\text { 1/4MS+IBA1.0mg/ } \\
\mathrm{L}+\mathrm{NAA} 0.5 \mathrm{mg} / \mathrm{L}\end{array}$ & $\begin{array}{l}60.0 \pm 10.4 \\
1 \mathrm{~b}\end{array}$ & $5.0 \pm 0.00 \mathrm{a}$ & $\begin{array}{l}1.4 \pm 0.0 \\
3 \mathrm{a}\end{array}$ \\
\hline N3 & $\begin{array}{l}\text { MS+IBA1.0mg/L } \\
\text { +NAA1.0 mg/L }\end{array}$ & $\begin{array}{l}55.0 \pm 7.64 \\
b\end{array}$ & $3.3 \pm 0.33 \mathrm{~b}$ & $\begin{array}{l}0.9 \pm 0.0 \\
3 c\end{array}$ \\
\hline N4 & $\begin{array}{l}\text { 1/2MS+IBA1.0mg/ } \\
\mathrm{L}+\mathrm{NAA} 0.0 \mathrm{mg} / \mathrm{L}\end{array}$ & $\begin{array}{l}36.7 \pm 4.41 \\
\text { c }\end{array}$ & $3.0 \pm 0.58 \mathrm{cb}$ & $\begin{array}{l}0.9 \pm 0.0 \\
3 c\end{array}$ \\
\hline N5 & $\begin{array}{l}\text { MS+IBA1.5mg/L } \\
\text { +NAA0.5 mg/L }\end{array}$ & $\begin{array}{l}33.3 \pm 6.01 \\
\mathrm{~cd}\end{array}$ & $3.0 \pm 0.00 \mathrm{cb}$ & $\begin{array}{l}0.9 \pm 0.0 \\
7 \mathrm{~cd}\end{array}$ \\
\hline N6 & $\begin{array}{l}\text { 1/4MS+IBA0.5mg/ } \\
\mathrm{L}+\mathrm{NAA} 1.0 \mathrm{mg} / \mathrm{L}\end{array}$ & $\begin{array}{l}25.0 \pm 2.89 \\
\text { cde }\end{array}$ & $2.3 \pm 0.33 \mathrm{~cd}$ & $\begin{array}{l}0.8 \pm 0.0 \\
3 \mathrm{de}\end{array}$ \\
\hline N7 & $\begin{array}{l}\text { 1/2MS+IBA1.5mg/ } \\
\mathrm{L}+\mathrm{NAA} 1.0 \mathrm{mg} / \mathrm{L}\end{array}$ & $\begin{array}{l}16.7 \pm 4.41 \\
\text { de }\end{array}$ & $3.3 \pm 0.33 \mathrm{~b}$ & $\begin{array}{l}1.2 \pm 0.0 \\
3 \mathrm{~b}\end{array}$ \\
\hline N8 & $\begin{array}{l}\text { MS+IBA0.5mg/L } \\
\text { +NAA0.0 mg/L }\end{array}$ & $\begin{array}{l}15.0 \pm 2.89 \\
\text { e }\end{array}$ & $1.3 \pm 0.33 \mathrm{e}$ & $\begin{array}{l}0.6 \pm 0.0 \\
3 \mathrm{f}\end{array}$ \\
\hline N9 & $\begin{array}{l}\text { 1/2MS+IBA0.5mg/ } \\
\mathrm{L}+\mathrm{NAA} 0.5 \mathrm{mg} / \mathrm{L}\end{array}$ & $\begin{array}{l}11.7 \pm 4.41 \\
\text { e }\end{array}$ & $2.0 \pm 0.00 \mathrm{ed}$ & $\begin{array}{l}0.7 \pm 0.0 \\
0 \mathrm{fe}\end{array}$ \\
\hline
\end{tabular}

Note: Letters following the numbers in the same line suggest significant differences $(\mathrm{P}<0.05)$

\section{CONCLUSIONS AND DISCUSIONS}

The cloning technique was used for plantlet culture since it happens to L. edulis as well as to most fruit trees that plantlets naturally produced with seeds mutate. Green cuttings are mainly applied to reproduction at present, but cuttings' sources cause low propagation coefficient. Tissue culture micro-propagation technology is an extension of traditional vegetative propagation techniques and has such merits as rapid propagation and high propagation coefficient, suitable for expanded propagation of a large number of excellent new varieties. There have been few reports home and abroad on techniques for in vitro culture and rapid propagation of $L$. edulis, and the current researches remain preliminary and fail to meet the production needs. Zhao Yue et $\mathrm{al}^{[6]}$ conducted researches on tissue culture and shoot regeneration of Lonicera kamtschatica Pojark. imported from Russia, the species also belonging to the $L$. edulis subgroup, by means of callus induction. The shoot propagation rate was only 2 to 3 times, rooting rate $85 \%$, and transplanting survival rate $90 \%$. The time was relatively longer, reproductive efficiency lower, which could hardly meet the needs of production. This project has been preceded by some preliminary studies on the technique of $L$. edulis shoot tissue culture which contributed to the optimum sterilization composition, basal medium and explant ${ }^{[7]}$, although the studies were not concerned with subculture and rooting compositions, and didn't develop experimental system of tissue culture or in vitro rapid propagation that is particularly suitable for production and application.

By using orthogonal design this study screened the optimal primary culture, subculture and rooting compositions of $L$. edulis, established its in vitro culture system, and laid the foundation for the industrialized breeding and cultivation. Under in vitro culture conditions, various plants' unique genetic, biological and ecological characteristics led to different nutritional requirements, which made it essential to choose the agreeable media for plant tissue culture. MS medium was mainly applied to shoot culture and bud induction. MS medium and their modifications were applied to shoot tissue culture of 36 out of 45 non-woody plants, and to bud induction of 70 out of 97 woody plants ${ }^{[9]}$. Comparative tests were conducted in this study between MS, $\mathrm{N}_{6}, \mathrm{~B}_{5}, \mathrm{H}$ and White media, which concluded that MS medium was the optimum shoot culture and bud induction medium, the differentiation rate $98.5 \%$.

An increasing number of trials have demonstrated the correctness of "hormone balance" theory presented by Skoog et $\mathrm{al}^{[10]}$, both cytokinin and auxin playing an important role in bud induction and growth. Combinations of different kinds and concentrations of hormones in media significantly affect induction and proliferation of $L$. edulis, which is the core of rapid propagation technology of $L$. edulis tissue culture. MS +6- BA $1.0 \mathrm{mg} / \mathrm{L}+\mathrm{IBA}$ $0.2 \mathrm{mg} / \mathrm{L}$ was the optimum medium for $L$. edulis multiple shoot induction, the average bud differentiation rate $100 \%$. Experiments showed that rapid propagation was hard to achieve on MS medium with 6-BA and IBA. 6-BA, KT, and the interaction of 6-BA, KT, and IBA had a highly significant impact on propagation of $L$. edulis in subculture, the effect of IBA being significant, which indicated that combinations of 6-BA, KT and IBA resulted in the increase of the number of multiple shoots in subculture, and was conducive to bud elongation. MS +6- BA $0.5 \mathrm{mg} / \mathrm{L}+\mathrm{IBA} 0.3 \mathrm{mg} / \mathrm{L}+\mathrm{KT} 1.5 \mathrm{mg} / \mathrm{L}$ proved to be the optimal medium that had the best effect on propagation in subculture, the proliferation coefficient being 8.7. Reduction of a large number of elements in basal medium caused adventitious roots, and $1 / 4 \mathrm{MS}$ proved to be optimal. IBA performed well in root induction, and generated more roots suitable for transplanting. 1/4MS + IBA $1.5 \mathrm{mg} / \mathrm{L}$ proved to be the rooting medium suitable for $L$. edulis, the rooting rate $96.7 \%$, with an average of 5 roots per micro-cutting, the root length up to $1.5 \mathrm{~cm}$.

\section{ACKNOWLEDGEMENTS}

The research work was supported by the Jilin Province science foundation projects (No.20120269, 20140307025NY), the department of education of Jilin Province science foundation projects(No. 2012130), and the central government forestry science and technology demonstration projects(No. [2013]TJQ04).

\section{CORRESPONDING AUTHOR}

Information about corresponding author: Qichang Zhang, zqc1212@sina.com, 18604498159 


\section{REFERENCES}

[1] Huo Jun-wei, Yang Guo-hui, Sui Wei \& Yu Ze-yuan. Review of study on gemplasm resources of Blue honeysuckle(Lonicera caerulea L). Acta Horticulturae Sinica, 32(1), pp.159-164,2005.

[2] Xiang Yan-ju, Zheng Xian-zhe \& Wang Da-wei. Recent advances of research about utilized values and prospects for exploration in Lonicera edulis Turcz. Journal of Northeast Agricultural University, 36(5), pp. 669-671,2005.

[3] Plekanova M N. Blue honeysuckle (Lonicera caerulea L.) - a new commercial berry crop for temperate climate: Genetic resources and breeding. Acta Horticulturae, 538, pp.159-163, 2000.

[4] Tanaka S, Kakizaki M \& Watanabe H. New blue honeysuckle (Lonicera caerulea L. var. emphyllocalyx Nakai) cultivar 'Yufutsu'. Bull Hokkaido Pref Agric Expt Sta, 67,pp. 1-9,1994.

[5] Xu Shuang-qing \& Wang Pei-qing. Techniques for culturing Blue honeysuckle. Northern Horticulture, 7, pp. 19,1989.
[6] Zhao Yue, Huo Jun-wei \& Wang Li-juan. Tissue culture and plant regeneration of Blue honeysuckle(Lonicera caerulea). Plant Physiology Communications, 39(5), pp. 468,2003.

[7] Liang Qi-lan, Zhang Qi-chang, Yang Zhen-guo \& Kou Guo-guang. On tissue culture of Lonicera Edulis. Journal of Beihua University(Natural Science), 7(6), pp.549-551,2006.

[8] Shang Xu-lan, Xu Xi-zeng \& Fang Sheng-zuo, A Preliminary study on embryo culture and rapid propagation in vitro of cyclocarya paliurus. Journal of Nanjing forestry university natural science edition,31(1),pp.101-105,2007.

[9] Yuan Qiao-ping, Biological technique and micro-breeding of tree in test tube. World forestry research, 3, pp.51-55, 1990.

[10] Skoog F, Miller C O. Chemical regulation of growth and organ formation in plant tissues cultivated in vitro. In biological action of growth substances Symp Soc Exp Biol, 11, pp. 118-131, 1957 